Short Communication

\title{
An Approach to Solar Rechargeable Flow Battery Based on Electroactive Organic Redox Couples
}

\author{
Wenhua Zhang ${ }^{1,2}$, Ping Liu ${ }^{3}$, Jia Liu ${ }^{1,2}$, Xiaopin Yang ${ }^{1,2}$, Xingwang Zhang ${ }^{1,2}$ \\ ${ }^{1}$ Nanchang Institute of Technology, Tianxiang Avenue No.289, 330099, Nanchang, China \\ ${ }^{2}$ Nanchang Institute of Technology, Jiangxi Province Key Laboratory of Precision Drive and Control, \\ Tianxiang Avenue No.289, 330099, Nanchang, China \\ ${ }^{3}$ State grid of Jiangxi electric power research institute, Minqiang Road No.88, 330096, Nanchang, \\ China \\ *E-mail: zhangwenhua_610@163.com
}

doi: $10.20964 / 2019.05 .55$

Received: 8 September 2018 / Accepted: 5 March 2019 / Published: 10 April 2019

\begin{abstract}
An integrated photo-electrochemical solar energy conversion and storage device is developed by a dye sensitized $\mathrm{TiO}_{2}$ solar cells and 2, 2, 6, 6-tetramethyl-1-piperidinyloxy (TEMPO) / 1, 4Benzoquinone (BQ) redox flow batteries. The device can be directly charged by solar light without external bias, and discharged like normal RFBs with an energy storage density of $3.5 \mathrm{mAhg}^{-1}$ over many cycles. The proposed device demonstrates a rapid photo-charge at light illumination and a stable electrochemical discharge in the dark, realizing an in situ photo-to-chemical-to-electrical conversion and photo-to-chemical storage.
\end{abstract}

Keywords: Solar cells; Rechargeable flow battery; Charge storage; Organic redox couples

\section{$\underline{\text { FULL TEXT }}$}

(C) 2019 The Authors. Published by ESG (www.electrochemsci.org). This article is an open access article distributed under the terms and conditions of the Creative Commons Attribution license (http://creativecommons.org/licenses/by/4.0/). 